\title{
THE HANSE IN MEDIEVAL AND EARLY MODERN EUROPE: AN INTRODUCTION
}

\author{
Justyna Wubs-Mrozewicz
}

\section{The Hanse Game}

Just for fun, let's imagine that the scholars who contributed to this volume did not meet at an international congress. Instead, they gathered to play a board game called 'The Hanse: 500 years in the Baltic and North Sea'. They enjoyed a bite of bread with herring and a good glass of beer, distributed pawns, joked about winning and cooked up crafty strategies. Yet, scholars being scholars, they first squabbled about the rules of the game:

Carsten: 'Why is Lübeck in the middle of the board? Come on, guys, there's gotta be a better starting point for the Game! After all, Lübeck wasn't the centre of the Hanseatic world from the word go. Also, nobody could count on selling his goods there, so "Go directly to Lübeck, collect 250 marks" is wrong.'

Edda: 'Wait, before we start: it's all about trade at sea. But the game doesn't have any instructions about what happens if something goes wrong, like shipwreck, piracy and stuff like that. Worse yet, the Hanse didn't have a unified set of rules about this. Each town made up its own. So we're gonna to have to work through those Jeopardy and Chance cards carefully before we start!

Sofia: 'Hey, that's true for all the other commercial regulations, like sales contracts. Each town had its own bylaws, just look at Scandinavia! And right at the beginning we can chuck that old bit of nonsense about how Lübeck law smoothed out all the differences that mattered. If anything, people faced with similar problems hit on similar solutions separately. So, Edda, I'm gonna be looking over your shoulder when you go through those Jeopardy and Chance cards! You keep your eyes on the sea, I'll keep mine on the land.'

Justyna: "Why are we calling this "The Hanse Game" anyway? I mean, it's not as though they never dealt with anybody else! And getting guys from all kinds of towns to get together in a tent with a "Hanse" 
sign outside was harder than herding cats. So at least in the Kontore like Bergen, we need some Interaction cards!'

Jim: 'Everybody's assuming the money comes out of the bank by magic. I mean, "Go directly to Danzig, collect 400 marks for cloth", is just ridiculous! You gotta ask how you get the money to buy the cloth in the first place. Not by rolling dice! So we need some Finance cards, maybe ones that can only be cashed in Bruges.'

Stuart: 'Hey, you're all assuming everybody's honest, but I've played enough Monopoly to know it ain't so. All the Game's got are Jeopardy cards telling you you've been rooked, but maybe we need some "Get Out of Jeopardy" cards to force people to cut square corners. Also, I'm not real happy about all these lines on the board telling you where to go. They all just send you from East to West and back again. But there are lots more places on the board than that, and the instructions don't tell us anything about how to connect up the dots.'

Mike: 'How are we supposed to know who's winning? I mean, how do we know that you always get 200 marks for a load of stockfish from Bergen? And how do we know that you make money on the whole? After all, as Jim said, you've got to buy the stuff before you can sell it, and there's no guarantee you won't get skinned!'

Marie-Louise: 'Where's the end point of the Game? When does the music stop: 1669 when the last Hanseatic Diet met? Or do we go on playing until the merchant networks folded up? Is the Game about politics or people, that's what I want to know!'

Stuart: 'I'm gonna get another beer. Anybody want anything while I'm up?'

(Scene fades...).

If it were only so easy! Board games are board games, but all authors in this volume contribute-in the measured and dulcet tones of the learned-to the academic game called 'Hanse studies', putting forward new points of view, contesting the opinions of previous scholars. And they are not shy about it. Debate lies at the very foundation of this volume. When some of the articles were presented for the first time at the World Economic History Congress in Utrecht (August 2009), there was a spirited discussion both among the speakers themselves and with those in the audience. The latter were economic historians studying commercial relations in premodern Europe, and as specialists in their own fields, they questioned the Hanse from all corners. Thus, the Hanse was set in a broader European discussion context, where it rightfully belongs. 
These 'internal' and 'external' discussions have shaped this book. On the one hand, the authors delve deep into their research topics and explore central questions about the Hanse and the sources, advancing knowledge in a field with long and robust research tradition. Yet their findings are not restricted to Hanse studies alone. Rather, they highlight issues which make the Hanse unique and atypical in the context of late medieval Europe. Several contributions draw on Mediterranean trade, the actions of nonHanseatic traders or theoretical debates on commerce and economy in late medieval and early modern Europe for comparisons. Furthermore, the authors seek to place the Hanse in a wider context by showing features and mechanisms which were intertwined with pan-European features and mechanisms. They discuss common roots, influences and parallel developments, as well as source and research problems which crop up when various parts of Europe are investigated. The leitmotif of the volume is the two sides of the Hanse: in many aspects a typical European phenomenon, but also unique, challenging and thus fascinating.

Consequently, the purpose of this book is also twofold. Aside from presenting specific new research results, the volume can also serve as a guide to Hanse studies. The authors' footnotes signpost the state of research on their topics, but not all research areas within the wider field of Hanse could be covered in this volume. That is a recurrent problem common to conferences and edited volumes. In this introduction, I will try to fill the gaps by sketching the state of research on the Hanse (part I, pp. 4-14) and summarizing authors' results and presenting various areas of research (part II, pp. 14-20), as well as by providing a list of selected sources and bibliography of the Hanse (p. 30). In the concluding chapter, Stuart Jenks will suggest the directions future Hanse research might — or should — take. It must be noted that most of the research done in the field of Hanse studies is in German or other non-English languages: the current volume will be one of the few book publications in English on the Hanse providing both new findings and a summary of the state of research. It is our hope that this presentation of the Hanse in its European context will stimulate medieval and early modern historians to pick up their end of the story and (re)integrate the Hanse in it.

Finally, the Hanse and Europe will be tackled from yet another angle in this introduction (part III, pp. 20-25). I will briefly sketch the use and abuse of the phenomenon 'Hanse' in (this time not late medieval) Europe. It is a hot topic at the moment, both in Hanseatic studies and in the higher and lower echelons of European political and economic integration. Quite remarkably, since the nineteenth century there have been many attempts 
to hijack the Hanse and make it serve national and European ideologies. Whenever the tune changes, the Hanse takes a different place in the musical chairs game. And as the changes are rung in the public sphere, they affect historical research on the Hanse.

\section{What was the Hanse?-Short Overview of the State of the Art}

Various studies of the Hanse have one thing in common: sooner or later, the question pops up 'What was the Hanse, actually?'1 It is usually followed by an audible sigh: 'It's complicated'. The most common problem of description is that the Hanse needs to be understood within its own particular legal and organizational framework. As it will be shown later, it differed in many aspects from other mercantile organizations in medieval and early modern Europe like merchant guilds, and from political structures like town leagues. Moreover, the way the Hanse worked is difficult to 'translate' into modern terms in a straightforward manner. Parallels with the EU, the EEC or the UN cover at best only some facets of the Hanse, not the whole of it. ${ }^{2}$ As an introductory mental tool, it is perhaps better here to draw a parallel to another theme of research on medieval Europe, one in which self-questioning and recognition of complexity is also taken as a point of departure: national or ethnic identities in the Middle Ages. There the recurrent issues are whether such identities existed, and if so, how they were built up. ${ }^{3}$ Both in the case of the research on the Hanse and on identities, the researcher tries to grasp the connections and mechanisms which hide behind notions which are all but hard-andfast. When it comes to the Hanse, there is a famous (and appropriately maritime) metaphor by Ahasver von Brandt: he described it as a mollusc: a strong, but also a changeable and a fluid body. ${ }^{4}$ The most conspicuous (and most commonly mentioned in research) aspect of its changeability is that membership in the Hanse was not fixed, and therefore its composi-

1 Henn (1999) and (2010); Hammel-Kiesow (2002); Selzer (2010). Compare Friedland (1991) and Stoob (1995). See also the contributions in Müller-Mertens and Böcker (2003) and Hammel-Kiesow (2003).

2 Hammel-Kiesow (2007).

3 Hoppenbrouwers (2010); Smith (2004); Jakobsson (1999).

4 von Brandt (1963) 29. Another water-borne metaphor can be found in the sources themselves: in the fifteenth century, the English accused Hansards of crocodile-like behaviour. The Hanse showed only its head (and implicitly: its teeth), while the rest of the body was hidden in water, see Selzer (2010) 36; Jörn (1998). 
tion changed from incident to incident. This makes it impossible to give a complete list of members of the Hanse and plot them on a single map: all maps of the Hanse are snapshots (see the map on pp. 26-29). Moreover, the contours of the Hanse, like these of national and ethnic identities in the Middle Ages, depend to a certain extent on the eye of the beholder. These boundaries are different if one analyses the political context, or if one chooses to focus on administrative and legal aspects of the organization, or if one investigates shared cultural traits (like language). And then again they are different in each period of investigation. In contrast to the discussion on medieval national or ethnic identities, however, there is a comforting consensus among Hanse scholars. The Hanse did exist.

So what was it, actually? In one of the most recent definitions, the Hanse was an organization of traders (specifically: traders speaking Low German and engaged in foreign trade) AND an organization of towns (up to 70 large and 100-130 smaller towns) in which these traders were burghers. ${ }^{5}$ The participation of towns in the Hanse was thus secondary, through their traders. ${ }^{6}$ Being part of the Hanse was only one aspect of their urban identity, and sometimes only a small one. ${ }^{7}$ This explains why the towns used the term 'Hanse' only in situations when common interests were at stake, and hardly ever in town chronicles or when they acted on their own account. ${ }^{8}$ Internally, the term gemener copman (common merchant) was preferred to 'Hanse' or 'Hanse towns', which shows again that the basis of the organization was people, not urban entities. ${ }^{9}$ When it was no longer enticing for traders of a town to conduct trade jointly with merchants from other Hanse towns, they (often silently) gave up their membership and their participation in common rights. Since the ultimate motive of traders was profit, they only played the Hanseatic game as long as it was profitable. Apparently, it paid off for a long time, since the Hanse existed for at least five hundred years, from the middle of the twelfth until the middle of the seventeenth century. ${ }^{10}$

5 Hammel-Kiesow (2002) 10.

6 Selzer (2010) 5 .

7 Henn (2010) 13; the contributions in Henn and Sarnowsky (2010).

8 For instance in interaction with the emperor, see Moraw (2002) 64. More general: Hammel-Kiesow (2002) 17; Behrmann (1997) and (2004).

9 Irsigler (1998); Friedland (1999).

10 There is no clear beginning or end of the Hanse, see the contributions of Carsten Jahnke and Marie-Louise Pelus-Kaplan, as well as the overview of the political and economic periodization of the Hanse further in this introduction. 
Shared interest, functioning as a common denominator for traders and towns involved in the Hanse, is a key notion in understanding the organization. It started with the shared interest of traders abroad, forming a group: the very term hansa means cohors, that is a 'troop' or a 'crowd'. It refers thus to a collective phenomenon, an appearance and action as a group. From the twelfth century, the term was used in Northwestern Europe in the context of trading communities which were active in longdistance trade, and whose members obviously needed each other's support, for self-defence if nothing else. From the late thirteenth century on, the term started to be used in reference to traders of 'the' Hanse. Yet it also referred to the tax these traders had to pay for being able to participate in the trade abroad. A third meaning of the word hansa was legal: it was the right to conduct trade jointly. This third meaning reveals the tectonic force underlying the gradual rise of the Hanse as an organization of traders, and later also of towns: cooperating to secure trading rights abroad. ${ }^{11}$ This cooperation of traders coming from various towns was on the one hand visible in the context of their meetings (the so-called Hanseatic Diets, most often held in Lübeck), ${ }^{12}$ and on a daily basis in the Hanseatic settlements abroad (especially the four largest ones, the socalled Kontore in London, Novgorod, Bruges and Bergen). ${ }^{13}$ From the late thirteenth century on, the word hansa started to be used in reference to traders of the growing organization which became to be known as 'the' Hanse. ${ }^{14}$ Its economic foundation was the exchange of goods in the Baltic and North Sea areas, transported primarily by sea, but also by river and land. If one wants to make a broad generalization, mass goods and raw materials from the north and east were exchanged for finished products, luxury goods and transit goods from the West and the Mediterranean. One mercantile organization thus connected various regions in Europe. ${ }^{15}$ The current state of research is that this Hanse was first and foremost a 'community of interest', not a hierarchical structure. ${ }^{16}$ There was no top-

11 Friedland (1991) 21-5; Hammel-Kiesow (2002) 27.

12 Henn (2001).

13 There were also several smaller ones, for instance in Oslo and Tønsberg, Norway, Bourgneuf and La Rochelle in France, Lynn and Boston in England; on the Kontore, see Angermann and Friedland (2002); Graßmann (2005); Schubert (2002).

14 Hammel-Kiesow (2002) 27.

15 The most common goods in the Hanseatic trade: furs, wax, wood, grain, fish (herring and stockfish, i.e. dried cod), textiles, beer, wine, salt, potash; Bund (1973) 5; Boer (200o); Hammel-Kiesow (1999) and (2002) 37.

16 von Brandt (1962) 7; Hammel-Kiesow (2002) 14-5; Selzer (2010) 10-1. 
down decision-taking in questions of trade or trade policies: all decisions taken at Hanseatic Diets had to be validated in each town and incorporated into its bylaws in order to be binding on the individual merchant. In principle, the Hanse was a network of peers (although some of them were in practice more influential than others, the emblematic example being Lübeck traders). Their interaction increased when it seemed profitable or (politically) necessary. Such a structure was correlated to the fact that the merchants of the Hanse operated in a large area, by European medieval standards. The towns where they were burghers and with which they traded were located broadly in the Baltic and North Sea area and their hinterlands. A loose and non-hierarchical structure made it possible for traders from towns distant from one another to join the organization and profit from the same privileges. This way, the Hanse could appear and act as a large, varied group of traders with a say in areas crucial to medieval European trade. As Carsten Jahnke points out in his contribution, 'the' Hanse became a successful collective brand name in Europe.

This brings us to a discussion which bears on the towns of the Hanse and the broader European medieval context. The 'community of interest' view on the Hanse disputes a very different viewpoint, mostly taken by earlier scholars, where the Hanse was seen as a top-down, hierarchical urban league. The literature commonly refers to this discussion as the non-hierarchical 'Gemeinschaft' versus the hierarchical 'Bund' debate. ${ }^{17}$ Urban leagues were common in medieval Europe, well-known examples being the 'Rheinischer Bund' or the Swabian League. ${ }^{18}$ The concept of the Hanse as an urban league would make it at least a recognizable, perhaps an emblematic European phenomenon. Yet the Hanse does not fit in this picture, it was far more unusual. It lacked several traits researchers have identified as being crucial for an urban league: there was no foundation act, no common seal, no executive power or treasury. Nor was it created for a specific, time-framed purpose. One member could not be held responsible for the actions of others. Also, the Hanse shared economic rather than political goals (although it used political means — war and diplomacyto achieve these goals). On the other hand, towns could simultaneously belong to the Hanse and an urban league, which accordingly could have an impact on the Hanse as a whole or some of the towns in it, but was

17 Wernicke (1983); Henn (1984). In his attempt to analyse the Hanse in a sociological model of strong and weak ties, A. Pichierri (2000) used the concept of the Hanse as an urban league (or even: a state of towns).

18 Distler (2006). 
just as clearly a separate, non-Hanseatic entity. ${ }^{19}$ Furthermore, there were attempts to add some of the elements of town leagues to the Hanse, by binding the towns in the so-called tohopesates. These military alliances were triggered by political_-rather than economic -interests. They were created with a (political) goal in mind and for a limited period of time. ${ }^{20}$ It must be pointed out that in the second half of the sixteenth century, attempts were made to reshape the Hanse into an urban league. These attempts have to be viewed from the context of the changes of power in late medieval and early modern Europe: states and princes became stronger, while towns lost much of their autonomy. Privileges for traders no longer worked to their economic advantage, and gradually they lost importance. Consequently, Hanseatic traders and their hometowns were forced to invent new ways to be a partner in commercial and political negotiations. One of them was to seek more defined organizational structures which made them fit better into this hierarchical world. ${ }^{21}$ In the context of this volume, it is important to underscore the fact that this post-medieval meaning which was added to the Hanse has influenced terminology in English. While 'Hansebund' has practically vanished from German scholarship as a term for the whole organization, 'the Hanseatic League' endures in the English-speaking context as fossil.

There was another European medieval form of organization-merchant guilds - which should be discussed in the context of the Hanse, focussing on traders. Like the Hanse, they were non-hierarchical, bottom-up organizations of traders. As Stephan Selzer recently pointed out, scholars use the term 'merchant guild' to cover various types of organizations functioning under various names in the Middle Ages. Among them are hansas of traders abroad, one of the early roots of 'the' Hanse. The common denominator of these organizations was that membership was voluntary, based on equality among all members and sealed by an oath. Membership in a guild had implications for various aspects of life, not only the professional ones. A well-known and currently intensely investigated element was religious life, as guilds often overlapped with confraternities. Sociability, especially commensality, was another feature, and it entailed frequent and direct contact between most if not all its members. Guilds and their members

19 Selzer (2010) 62.

20 See for instance the unsuccessful attempt to create such an alliance in 1418, and a successful one in $145^{1}$ (for the period of six years), see Selzer (2010) 62-3.

21 Postel (1999); Blockmans (1993); Heerma van Voss and van Nederveen Meerkerk (2007). 
were also connected to a specific location. Moreover, the fundamental rule for guilds was that members were to help each other in plight. Guilds had their own internal administration, jurisdiction and seal. ${ }^{22}$ There were many local merchant guilds in the towns of the Hanse, uniting, as in the case of Lübeck, traders active on a specific foreign market like Flanders or Bergen in Norway. These merchant guilds were pillars of Hanseatic trade, and the Hanse fits very well indeed into the general European tradition of bottom-up organization of trade. ${ }^{23}$ Also, Hanseatic settlements abroad (Kontore and smaller settlements) might be seen as merchant guilds in the diaspora (alien merchant guilds). ${ }^{24}$ However, the Hanse as a whole was not a mega-guild of traders (if we follow the guild concept sketched above), as it has been recently claimed by economists and some economic historians. Its members swore no oath to other Hansards in general, but did so only when they joined a Hanseatic Kontor abroad. The Hanse was marked off from guilds because there was (for most of the period) no shared internal administration, treasury or seal; there was no real coercive power towards its members (as paradoxical as it may sound); there was no pan-Hanseatic memoria culture; and finally, sociability and direct contact was limited to the (infrequent) meetings and involved only a very small number of Hanse merchants, who were envoys to these meetings. ${ }^{25}$

22 Oexle (1989); Schmidt-Wiegand (1999); Selzer (2010) 26-9. This interpretation of medieval (merchant) guilds encompasses 'bodies which were called gilda, but also confratria, consortium, fraternitas, societas, coniuratio, amicitia and other', see Oexle (1989) $145^{2}$.

23 Asmussen (1999); Burkhardt (2009). Many of these guilds outlived the Hanse itself, for instance the Bergenfahrer. Apart from the fact that merchant guilds offered economic benefits to its members, something which might in part explain their longevity in European economy, see Ogilvie (2011), the complex social glue of rules and traditions must have played a role.

24 Ogilvie (2011); Wubs-Mrozewicz (2011). The Kontore had an internal administration, jurisdiction and rules of conduct, seal, treasury and an oath was given when a trader became member. Also, conviviality and commensality were important, and there was a memoria culture.

25 Fahlbusch (1994); Czaja (2000); Henn (2002). It must be noted that these economic historians and economists use a wider concept of merchant guilds, which is more or less equivalent with 'merchant associations'. This concept focuses on the economic aspects of the activities of (long-distance) merchants. To encompass various types of merchant associations, also very loose ones, the term covers also ad hoc groups with little or no juridical, administrative and social structures. In this take, the Hanse is also seen as a merchant guild, see especially Ogilvie (2011) and Grafe and Gelderblom (2010) and the literature cited there. However, it means attaching a label to the Hanse which is too broad to capture its paradox as an organization both of traders and towns; the paradox that is was a recognized economic and political power in the Middle Ages, but it lacked coercive power towards its own members; and the paradox that it refused to define its legal boundaries while it operated within very broad geographical boundaries. 
This all is understandable from the organizational point of view if we take the geographic extent of the Hanse into account. So the Hanse was not a town league and not a guild, but relied on town administrations and local (as well as alien) guilds in order to function.

What made the Hanse outstanding and successful in medieval Europe? There are several features which ought to be mentioned. It must be stressed that if one chooses to look at these features individually, they are not unique to the Hanse, but rather of the economy and culture of medieval Europe in general. It is the combination of these features which was unique. This allowed Hanse traders to act as a group. Only a brief sketch can be given here. First of all, the organization of the Hanse as a well-informed network of peers was of crucial importance. This network relied on the one hand on (extended) family ties, and on the other on the choice of trading partners both close and far from one's hometown. Especially in the latter case, mutual trust was key in relations. The business relations were based on reciprocal help in the purchase and sale of each other's goods. As Stuart Jenks shows in his contribution, the attitude was rather to create incentives to honest trade than to create a system of punishments. In order to maintain this person-oriented way of trading, a good reputation (the Hanseatic word is gelouwe) was imperative. The loss of one's good name meant exclusion from the trade network, and in some cases even from the Hanse as a whole. ${ }^{26}$ If you were part of the network, you benefited from the efficiency of the information flow within the Hanse: information was exchanged during Hanseatic meetings, in the Kontore and in letters between traders and towns. ${ }^{27}$ It is clear that merchants took great care to obtain and disseminate information as part of (internal) conflict resolution. ${ }^{28}$ Literacy was a pre-requisite for taking part in the extensive Hanseatic trade and information network. ${ }^{29}$ In addition, the fact that the whole Hanseatic network could use Middle Low German as a lingua franca in speech and in writing (most of the sources from the fifteenth and sixteenth century are in the vernacular) eased communication and bound traders to one another. ${ }^{30}$ An important part of the exchange of information concerned quality control. This was organized

26 Selzer and Ewert (2001); Puhle (1999). See also the contributions of Marie-Louise Pelus-Kaplan and Stuart Jenks in this volume.

27 See also Jenks (2010); Henn (2002).

28 Wubs-Mrozewicz (2006).

29 Henn (2002); Wriedt (2005). One did not have to be personally literate, but one's firm did: Jenks (1992).

30 Peters (1987); Fouquet (2006); Niebaum (2010). 
collectively, in the towns and especially in the Kontore, for instance to ensure that the quality of cloth (Bruges) or fish (Bergen) was checked and properly marked. Norms for weights and measures were also agreed upon collectively. This was one of the tools for cutting individual traders' transaction costs (they did not have to carry out the checks themselves) and thus make it profitable for them to join the Hanseatic network. ${ }^{31}$ Another one was that collective privileges abroad were made accessible to a wide and (until the middle of the fifteenth century) inclusive group of traders coming from various towns. Cost-efficiency was also apparent in the simple, single-entry bookkeeping, which was anything but backward in comparison to the Mediterranean trade, as Stuart Jenks argues in his article. ${ }^{32}$ This 'keep it simple' principle, and the possibility of joining a business partnership where one's input was work and not capital, opened the way for merchants without much experience or means to Hanseatic trade. Many traders could work their way up. Research has demonstrated that in the Hanse this resulted in a situation quite different from the mercantile world in southern Germany or the Mediterranean. In the latter two cases, a handful of traders and entrepreneurs garnered great wealth, while in the Hanse the middle strata of well-off merchants was much broader. ${ }^{33}$ Apart from being active in trade, they were also involved in (urban) politics by being part of the town council or being envoys to negotiations with other (Hanseatic) towns or (foreign) rulers. This meant that they could exert both economic and political influence on Hanseatic trade. ${ }^{34}$ Finally, apart from functioning as a kinship, mercantile and information network, the Hanse catered for the potentially rivalrous groups within it. Being part of these groups was less voluntary, or at least less self-directed than being part of trade networks. The prime example is life in the Kontore: after becoming part of a Kontor, a trader had to get along with merchants from other towns, who were not and often would not become part of their direct trade, kinship or even friendship networks. The Hanseatic traders in the Kontore enacted rules and devised ways of life which were to ensure that they would protect and not interfere in each others' business. ${ }^{35}$ This was exceptional in Europe: the outposts abroad

31 Jenks (1996) and (2005); Selzer (2010) 93-5.

32 Hammel-Kiesow (2008).

33 Selzer (2010) 97-8.

34 Pitz (2001); Moraw (2002).

35 Jörn (2000); Schubert (2002); Wubs-Mrozewicz (2008). See also the example of Hildebrand Veckinchusen in Böcker (1999). 
catered for the interests of traders coming not only from one town (like the Venetians in Bruges), but for traders originating from various towns. ${ }^{36}$ Last but (by no means) least, the geographical extent of the trading area of the Hanse was remarkable and unique: 'from the Urals to Portugal and Greenland to Central Germany.'37

When did the Hanse begin? When did it end? Again, there is no straightforward answer. It depends whether one takes a more Hanseatic (largely political and organizational) or a European (largely economic) view. In older research, the stages of development of the Hanse were measured by political events. The foundation of Lübeck (1143/1159), for a long time misleadingly presented as 'the birth of the Hanse', was certainly a crucial element in the whole series of foundations of towns in the Baltic. Yet it was not the towns as such, but the individual merchants and councillors of these towns whose activities gradually built up the Hanse, as Carsten Jahnke shows in his contribution. There were several other 'events' in the history of the Hanse which earlier scholars presented as turning points. Only a few can be highlighted here, namely those which have been misinterpreted, and these misinterpretations have proved long-lived, both in research and in publications for a general readership. A prime example is the beginning of regular Hanseatic Diets (meetings) from 1356, ${ }^{38}$ which earlier scholars erroneously viewed as the moment when the Hanse of traders was replaced by the Hanse of towns. As mentioned earlier, towns were members of the Hanse through their burghers, not the other way round. What can be claimed for this period, however, is that the organization of the Hanse became more tightly cinched (especially regarding the Kontore), and the town councils were involved in this process. ${ }^{39}$ Another example was the conflict with the Danish king Valdemar IV Atterdag in the 1360 s, which triggered the establishment of the Cologne Confederation in 1367 . The Confederation's victory was sealed by the Peace of Stralsund (1370), which earlier scholars presented as 'the' political highpoint of the Hanse and the beginning of the high summer of the Hanse which would last until the $1470{ }^{40}$ As it will be shown in the last section of this introduction, the 1370 treaty was re- and misused as a point of reference in the

\footnotetext{
36 Selzer (2010) 85.

37 See the contribution by Carsten Jahnke in this volume.

38 Although the problem of what criteria a meeting of town representatives had to fulfil in order to be called a 'Hanseatic' Diet is vexed: Henn (2001) 1-3.

39 Henn (1984).

40 Schwebel (1970); Henn (1994) 388-9; Jörn (1998b).
} 
nineteenth century. However, the Cologne Confederation was a political alliance which only partly overlapped the Hanse (more towns and traders were absent than present, among them the eponomous Cologne), so it is questionable whether the Treaty of Stralsund should be used as a flagship for Hanseatic political history. The fifteenth-century conflict between the Wendish towns and Holland (1438-1441) was at times erroneously presented as a Hanseatic-Hollandish war. Also, it was far too often presented as the result of growing Hanseatic-Hollandish competition in the Baltic (borne by the teleological thought that Hollanders would gain the upper hand there later) and the outburst of strong mutual antagonism. In fact, the conflict was largely about the payment of damages for privateering, and cooperation between both sides continued. ${ }^{41}$ The 1554/1557 attempt to reorganize the Hanse as a town league has on the one hand spawned the erroneous notion that the Hanse was - or ought to have been - a town league, and on the other hand that it was the involuntary twitching of a dying man. ${ }^{42}$ As mentioned earlier, it should be rather seen in the context of the political changes which took place in Europe at that time. The last Hanseatic Diet (1669) has often been presented as the final moment of the Hanse: yet in fact envoys from only a few towns participated in the meeting, and Lübeck, Hamburg and Bremen carried on their trade under the Hanseatic brand name. As Marie-Louise Pelus-Kaplan shows in her contribution, the Hanse lived on in many aspects.

If one wants to tell the story of the rise and decline of the Hanse from a European economic point of view, the periodization is quite different, as Stephan Selzer recently pointed out. The Hanse emerged during the period of explosive economic growth in Europe which lasted from the eleventh to the middle of the fourteenth century. ${ }^{43}$ According to Rolf Hammel-Kiesow, three conditions were of prime importance for the expansion of Hanseatic traders: first the inclusion of the Baltic in the trade system; second, the increased demand for goods in consequence of population growth at third-world rates from the twelfth century; and finally, the growing urbanization of Northwestern Europe. ${ }^{44}$ Under these circumstances, traders united under a brand name and chose to safeguard their rights in a large group. From an economic point of view, as Selzer

\footnotetext{
41 Seifert (1997).

42 Postel (1999).

43 Selzer (2010) 45; compare Pitz (1984).

44 Hammel-Kiesow (2002) 21-6.
} 
stresses, the heyday of the Hanse lay around 1300.45 Thereafter, the strains on agrarian production, combined with climate change and the Black Death in the middle of the fourteenth century, made life more difficult not only for the average man, but also for the average Hanseatic trader. The politically halcyon days between 1370 and the 1470 stood in stark contrast to the everyday struggle to transport one's goods safely (piracy and robbery were rife), sell it at a profitable price (without running into conflict with the locals or their rulers, who could grant or rescind privileges) and in turn purchase goods which would not prove to be counterfeit (as many new products and their imitations were coming on the market, for instance woollen cloth). On the other hand, the period which has traditionally been seen as witnessing the (political) disintegration of the Hanse: the sixteenth century and later, was in fact an economic boom time both in Europe and for traders in the Hanse. The number of Hanseatic ships rose significantly, and the Hamburg, Bremen and Danzig found ways to integrate their trade in the emerging Atlantic economy. ${ }^{46}$ And the last section of this introduction will show, even today the 'Hanse' is still eagerly sought as a brand name to sell all sorts of goods and services in Europe. So we are only stretching the point slightly if we say that the Hanse has never really disappeared from European economy.

\section{The Hanse in a Late Medieval Context: Deep Dives and Bird's Eye Views}

The contributors to this volume have all focussed on their respective research areas. The articles are thus deep dives in the Hanseatic archives and in the scholarly discussions pertaining to the Hanse. The references provided in them signal recent secondary literature within such areas as: the origin and growth of the Hanse; the organization of Hanseatic trade; legal history of the Hanse; interaction with non-Hansards and questions of identity; motivation in Hanseatic trade; source criticism and quantitative analysis; transitions in the Hanse in the early modern period. Moreover, all authors have placed their findings in the broader context of European history.

Carsten Jahnke elucidates the origins of the institution 'the Hanse' within a broad political and economic context. 'The City of Lübeck and the Internationality of Early Hanseatic Trade' questions an old dogma,

\footnotetext{
45 Selzer (2010) 44-5.

46 Graßmann (1998); Bogucka (2003); Pelus-Kaplan (2007); Selzer (2010) 107-14.
} 
namely that the origin of the Hanse should be sought in the foundation of Lübeck (1143/1159). In fact, he finds that the town was founded as a regional trade centre, and remained a minor player for a considerable time. Yet Lübeck undoubtedly had a key role in shaping the organization in the thirteenth century. Jahnke shows how 'the' Hanse came into being as a result of a special need for the protection of rights, namely when Lübeck traders lost their 'Danish' rights abroad in 1227, notably in London, and when they had to secure their rights in Flanders in 1252/1253. A new, effective brand name was need to attain a special position, and the universi mercatores Romani imperii proved to fit the bill. The power of the Hanse was born out of weakness and need. Moreover, when putting the Hanse in a broader framework, he points out that the city of Lübeck, as well as other Baltic towns, achieved a unique degree of symbiosis between merchants, lesser nobles and artisans. This released resources which were crucial for the growth of the Hanse. From a European and medieval point of view, Jahnke hangs a question mark at the predicate 'German' in the discussions of the Hanse, especially its content at the time. He also argues that in its collective form, the Hanse was a typical organization of medieval Europe. However, its longevity and its size (stretched out over a huge area), as well as the degree to which it, as an economic organization, used political means, made it unusual in the European context.

In his article 'The London Steelyard's Certifications of Membership 1463-1474 and the European Distribution Revolution', Stuart Jenks argues that next to the well-known pre-modern revolutions like the Commercial Revolution and the Consumption Revolution, another sea-change took place in the European economy in the fifteenth century: the Distribution Revolution. It had a significant influence on the world of the Hanse, and as such the Hanse is a good example of the transformations of trade in Europe in the fifteenth century. In short, as a hierarchy of markets emerged in Europe, traders gradually concentrated on specific markets one step up the chain, and this growing degree of specialization was evident in the Hanseatic outposts abroad, the Kontore, where it becomes apparent that Hanseatic trade was being funnelled through a very small number of ports. He builds his argument on a close reading of the so-called Guildhall certificates (of the Hanseatic Kontor in London). At the same time, he resolves several source critical issues connected to the certificates which have until now proved misleading for the interpretation of this source. By doing it, he gives a comprehensive demonstration not only of the complexity of this very source, but also of sources for the economic history of medieval Europe altogether. 
In 'Der ehrbaren Hanse-Städte See-Recht: Diversity and Unity in Hanseatic Maritime Law', Edda Frankot breaks a lance for the interpretation that Northern Europe lacked one common sea law in the Middle Ages. She argues that the Rôles d'Oléron (customary sea laws put in writing by at least 1286) were not used as a universal sea law in the Hanseatic world, and the decisions taken at the Hanseatic meetings were not mere amendments to the Rôles. Instead, Frankot shows on the basis of numerous examples and legal cases from Lübeck, Hamburg, Riga, Kampen, Aberdeen, Danzig, Reval and elsewhere that each town had its own rules concerning sea issues. Pan-Hanseatic regulations were only drawn up if there were gaps in the legal framework which disadvantaged Hanseatic traders. However, these decisions were only legally binding for a Hanseatic trader if they were incorporated in the bylaws of his own town. This was true even of the 'Hanseatic Sea Law', which was finally drafted in 1614. In general, Frankot stresses, Hanseatic traders were used to dealing with this diversity of sea laws. In this aspect they followed a general European pattern: diversity, not uniformity was the norm.

Sofia Gustafsson also argues for diversity in another take on legal history in her 'Sale of Goods around the Baltic Sea in the Middle Ages'. She focuses on sales contracts, specifically the right to purchase and to cancel a purchase. Gustafsson discusses both the rules and the customs of sales contracts, along with symbolic acts which made the contracts valid. Contrary to the received doctrine that Lübeck law influenced virtually every Northern European legal system, she demonstrates that there was no distinct influence from one source. Rather, one should speak of diversity and differences in the various town laws. When similarities can be spotted, Gustafsson stresses, they were due to parallel developments and can be seen as an expression of a common Northern European town culture.

In her contribution 'Hansards and the 'Other'. Perceptions and Strategies in Late Medieval Bergen', Justyna Wubs-Mrozewicz analyses the interaction of Hanseatic traders in Bergen, Norway, with Norwegians, Hollanders and Englishmen. She demonstrates that on the one hand, this interaction followed general European patterns of contact between foreign traders and their hosts, customers and competitors. Yet on the other hand, she argues, Hanseatic traders stood out in Europe because they made a particular distinction between all that was Hanseatic and all that was non-Hanseatic. 'Non-Hanseatic' was an umbrella term for various 'national' groups, and it gained importance from the fifteenth century 
on. In theory, a Hansard was to limit his business and social contacts to other Hansards. In practice, there were close contacts on various levels, and they were tolerated as long as the overall interest of the organization was not endangered. From the Hanseatic point of view, the term 'nonHansard' (just as 'Hansard') was a chameleon in content and connotation (positive, negative, neutral). The multifarious perceptions of and interactions with non-Hansards as the 'Other' disclose what 'Hanseaticness' meant at a given moment.

James M. Murray traces the 'Hanseatic' content of the history of Bruges in 'That Well-Grounded Error: Bruges as Hansestadt', and discusses the recent echoes of this past in present cultural initiatives. He shows that Hansards in many aspects followed the same patterns of trade and life in Bruges as other foreigners. They were, however, an atypical group because they were particularly numerous. Also, the degree to which they were involved in the religious and charitable life of Bruges made them stand out as a group among Italians, French, and Iberian merchants. Murray also asks what constituted the main attraction to Bruges for Hanseatic traders in the fifteenth century. Was it still the function of the town as a trade centre? Or was it its function as a financial market which made traders venture there?

In 'Small is Beautiful: Why Small Hanseatic Firms Survived in the Late Middle Ages', Stuart Jenks takes issue with the so-called 'backwardness' of the Hanse in the European context, a view put forward by Wolfgang von Stromer. Specifically, he focuses on the question of why the Hanse managed to survive and prosper for such a long period. He discusses some aspects of this enigma in depth: the fact that Hanseatic firms were small and that Hanseatic traders could enter several partnerships. This allowed them to be flexible and grasp opportunities where they arose, as well as to spread risks. Hansards also had several tools at hand to cut the cost of bookkeeping, information gathering and quality control. These tools enabled them to be no less successful than their Italian or South German counterparts. The second argument of the article rejects the view that the Hanse was the prime example of a private-order, multilateral reputationbased organization (as suggested by Greif and González de Lara). Were that to be the case, then the mechanisms of internal control would rely largely on the threat of ostracism and punishment of malfeasance. The Hanse, Jenks argues, was instead governed by incentives to conduct honest trade. The very organization of it as a network of peer partnerships stimulated transparency, reciprocity and quick access to information. This 
was a different way of handling problems of control than for instance in Venice.

Mike Burkhardt discusses a major source critical problem in his article 'Business as Usual? A Critical Investigation on the Hanseatic Pound Toll Lists'. He analyses the pound toll lists of Lübeck, which was a toll levied irregularly in Hanseatic towns in order to finance military actions. It is a source which has been used repeatedly to make comparisons to the volume of Mediterranean trade. A close reading, however, reveals that the source is not as reliable as researchers have thought. Analyzing the customs returns, the Hanseatic Bergen trade and individual traders, Burkhardt shows that there is too little exact information on the goods shipped, so that the analysis generates more questions than answers. Given the fact that the toll was levied only in special circumstances, and that pound tolls lists have survived for no more than eight years of the Middle Ages, Burkhardt warns against generalizations. Placing the issue in a broader context, he poses the question to what extent calculations of medieval sources give a reliable picture of European medieval trade.

Finally, Marie-Louise Pelus-Kaplan deals in 'Mobility and Business Enterprise in the Hanseatic World: Trade Networks and Entrepreneurial Techniques (Sixteenth and Seventeenth Centuries)' with the phase of transition of the Hanse, and puts it both in a retrospective and in a European context. On the basis of merchant archives (some of which have recently become available for research, namely the $1575^{-1583}$ account book of Hans Moller which was recovered after the dissolution of the Soviet Union), she demonstrates that the sine qua non for Hanseatic traders was mobility. Also, Pelus-Kaplan shows that this mobility was connected to the fact that Hanseatic business enterprises were usually based on family ties. In agreement with the picture sketched by Jenks for the earlier period, she argues that the simplicity of the organization of business relations in the Hanse allowed individual traders to be flexible and adapt to new circumstances. Hanseatic firms still flourished long after the Hanse as a whole lost its economic and political impetus. Looking at the Hanse in this broader European context of growth in the early modern period, one should see it as 'a vast series of family and commercial networks ceaselessly adapting themselves to changing circumstances, using very flexible and at the same time often pragmatic entrepreneurial techniques'.

There are several areas of research on the Hanse which could not be covered in this volume. Which of these areas are crucial if one wants to take a broad European perspective? First of all, one vital field deals with 
the connections between trade and artisanry, in terms of trade both with goods produced in Hanseatic towns (especially beer) ${ }^{47}$ and outside of them (especially cloth). ${ }^{48}$ This research shows the importance of Hanseatic trade not only for the distribution of goods, but also of ideas in Europe, for instance the use of hops in beer brewing, and of the impact it had on the growth of urban centres and the specialization of whole regions, for instance the development of Flanders as a cloth-producing region. When one focuses on the trade in foodstuffs, one sees how important it would be to investigate the role Hanseatic traders took in creating the culinary dividing line between butter and beer (Northern Europe) and olive oil and wine (Southern Europe). ${ }^{49}$

Another area is shipbuilding: the origins of the Hanseatic cog and its influence on later maritime architecture are inseparable from European maritime history in general. ${ }^{50}$ Also, the religious life of Hanseatic traders both in its unifying and dividing aspects has to be viewed in a broader European framework: for instance in the medieval religious culture of confraternities and memoria, ${ }^{51}$ or the spread of Reformation in Hanseatic towns and in the outposts of Hanseatic trade. ${ }^{52} \mathrm{~A}$ well-developed research area which cries out for a European perspective is 'Hanseatic' art and architecture. The quotation marks refer here to the discussion to what extent one can speak of Hanseatic art, whether it is supposed to mean art produced in Hanseatic towns, or disseminated by Hanseatic traders and exerting influence on the local art production. ${ }^{53}$ In parallel, there is debate on whether the brick buildings of many Hanseatic towns (showcased nowadays in tourist flyers) demonstrate the existence of typically Hanseatic features, and whether the spread of brick architecture along the Baltic shores can be understood as a proxy of Hanseatic influence. Both in the case of art and architecture, the debate is what should be seen as 'Hanseatic', and what as 'general European'. Furthermore, the education of Hanseatic traders is of importance in the context of increased (lay) literacy and numeracy in late medieval Europe. Burgeoning long-distance trade made it necessary for traders to develop good skills in writing, counting, Latin, the knowledge of goods, weights, measures and currencies

47 Blanckenburg (2001); Unger (2004).

48 Holbach (2007); Munro (1994); Stabel (2000); Abraham-Thisse (2002).

49 Mohrmann (1996).

50 Paulsen (2010); Ellmers (2010).

51 Poeck (1991); Rahn (1999); Rößner (2001); Graßmann (2009).

52 Postel (2009); Grassmann (2009b).

53 Zaske (1986); von Bonsdorff (1993); Nordhagen (1994); Pilecka (1994); Jaacks (1999). 
in Hanseatic trade, as well as of geography, law and administration. This led to the establishment of non-clerical town schools in Hanseatic towns under the patronage of town councils and merchant elites from the thirteenth to the fifteenth century. ${ }^{54}$ Also, the need for higher education increased. At the same time, the emergence of universities in Rostock (1419) and Greifswald (1456) can be seen as part of the general wave of establishment of universities in Europe. ${ }^{55}$ Finally, the language of the Hanseatic traders, Middle Low German (one of the distinctive features of the Hanse) should be considered in a broader European context. As a lingua franca in a large region it was one of the most prominent languages in medieval Europe. Since it was widely used both in a written and an oral form, it constituted an important counterpart to medieval Latin. And on the other hand, Middle Low German exerted a strong influence on the languages of the places to which Hanseatic traders ventured. This influence proved especially profound and lasting in Scandinavia: especially in Sweden and western Norway it led to a vast number of loan words, and to the changes of syntax. ${ }^{56}$ The impact of Hanseatic presence in Northern Europe speaks for itself.

\section{The Hanse and Europe}

The definition and redefinition of the Hanse in a European context is not only relevant for the Middle Ages and the early modern period. The history of the Hanse became a subject of research in the nineteenth century, in a time when the Holy Roman Empire dissolved (1806), when the map of Europe was set to change several times. The first modern historian of the Hanse, Georg Friedrich Sartorius posted a 'status update' of the Hanse in 1802: it was no longer a matter of contemporary politics, but it has turned into a 'safe' historical subject, a 'halbvergessene Antiquität' ('a nearly forgotten antique'). ${ }^{57}$ It brings to my mind a dusty piece of old furniture, which has stood in the corner for so long no one remembers which maiden aunt put it there. It is quite ironic that it was soon to be politicized in various ways. To push the metaphor further, since then this Hanseatic antique has proved to be chest of drawers filled with impressive

\footnotetext{
54 Schildhauer (1984); Jenks (1992); Wriedt (2005).

55 Asche (1999); Wriedt (2005).

56 Peters (1987); Dalen (1994); Jahr (1995); Rambø (2008); Niebaum (2010).

57 Sartorius (1802-1808) 6.
} 
memories of the past (often drawn out at random), a seat on which various ideas of leadership were throned, and a table to display commercial interests and diverse merchandise. With a bit of polishing and a lick of paint of the latest fashionable shade, the Hanse has been turned over and over again into a versatile furnishing.

The use and reuse of the Hanse is well-apparent in the context of German national history. It is a recurrent topic of self-reflection in recent scholarship. ${ }^{58}$ Remarkably, every couple of decades, different aspects of the Hanse came to the fore in the discussion of national history. The approach to the Hanse as a theme in national history, however, also had consequences for its interpretation in a European context. After Sartorius' academic approach, the first round of recycling the Hanse concerned the prominent role traders took as town councillors and burghers of largely independent towns. They were seen as the true carriers of German values, and the wealthy citizens of towns in the nineteenth century proudly imagined themselves as their heirs. Hanseatic (medieval) burghership was thus the key notion. A national myth of northern burghership, as opposed to the world of emperors, kings and nobles of southern Germany, was created. ${ }^{59}$ The archivist Johann Martin Lappenberg, when applying to a South German body for funds for the edition of sources relevant for Hanseatic history, pointed out that the Hanse was of supreme value for national history. It is enlightening that he saw the need to put the stress on national history, the European aspect apparently being self-evident. ${ }^{60}$ In this take, Europe was the vast market in which German burghers could act as independent entrepreneurs. The Hanse, as a powerful urban organization, was the outstanding German imprint on European mercantile history in the Middle Ages. The following turn in Hanseatic historiography was concurrent with rise of the Second German Empire (1871), and the establishment of the Hansischer Geschichtsverein in 1870/71 (with its journal, the Hansische Geschichtsblätter as a central organ for research on the Hanse and scholarly editions). The Hansischer Geschichtsverein came into being in connection with the quincentenary of the Peace of Stralsund (1370). This 'German' victory over Denmark, viewed as the apex of Hanseatic political might (see the discussion in part I, pp. 12-13), was linked

58 Henn (1994); Hill (2001); Hammel-Kiesow (2007); Selzer (2010). See also the contribution of Carsten Jahnke in this volume.

59 Schwebel (1964) 17-9; Henn (1994) 396-9.

60 Henn (1994) 397; Hill (2001) 75. The main Hanseatic source series: Hanserecesse/ Hanserezesse (1870-1970); Hansisches Urkundenbuch (1876-1939). 
to the contemporary Schleswig-Holstein question. In imperial Germany, Hanseatic historiography followed the general political course and turned to the sea. The maritime aspect of the Hanse was thus highlighted. The medieval Hanse was glorified for its mastery of the seas, and used to justify the expansion of the German fleet. Research was closely intertwined with political propaganda, as it appears from some of the (popular) writings of the scholars Dietrich Schäfer and Walther Vogel. The Hanse was presented as part and parcel of Germany's maritime past and future. ${ }^{61}$ In this imperialistic context, Europe was to be subdued once again by the maritime power of Germany. In Nazi Germany, the Hanse was again seen as a convenient past image of power and expansion. This image was used in a rhetoric which was to affect Europe deeply. The stress was this time on the economic expansion of Hanseatic traders in the Baltic, an area which was now seen as a 'German' inheritance from the Hanseatic past, infamously labelled Lebensraum. The socio-economic turn in the research on the Hanse, and in part its appropriation by the Nazi propaganda, was heralded by Fritz Rörig. The Hanseatic trader turned into the paragon of Germanic virtue, and a prime example of the superiority of German entrepreneurship, culture and law in Europe. The drive of Hansards to conquer new markets was used as a justification for German military expansion in the 1930 and 1940 s. $^{62}$ Other historians justified Nazi ideology by way of reference to the Hanse, and in turn used elements from the Hanseatic past to feed Nazi propaganda. For instance in the case of the Netherlands, the occupation of 1940-45 was first presented as 'natural' in view of the cooperation of Hollandish and Hanseatic traders, or even by presenting Hollanders as part of the Hanse. ${ }^{63}$ Later on, the occupation was justified by way of reference to the Hollandish expansion and the Hanseatic demise in the late Middle Ages and the early modern period. According to Karl Pagel, it could have all been prevented by a timely incorporation of Hollanders 'in den Bund der blutsverwandten niederdeutschen Städte' ('in the league of the Low German cities related by blood'): in other words, it was best to keep Hollanders under control, whether in the Middle Ages or in the $1940{ }^{6}{ }^{64}$ The expansion and ultimate fate of the medieval Hanse

61 Schäfer (1913); Vogel (1915); Henn (1994) 399-407; Hill (2001) 75-8.

62 Rörig (1940). The work of Rörig had also positive effects, namely freeing Hanseatic research from the political focus, and stimulating the investigation of the economic, social and cultural history of the Hanse, Henn (1994) 407-12; Hill (2001) 80-6.

63 For an overview of the question of Hollanders in the Hanse, see Seifert (1997).

64 Pagel (1943) 166; Wubs-Mrozewicz (ESSHC paper 2010, in preparation for publication). The work of Pagel is usually presented as an example of scholarship which resisted 
(and, indeed, of medieval Germany) was thus made to serve as the handmaiden of contemporary debates about the 'role' of Germany in Eastern and Western Europe. In the post-war period, the work of Rörig had also positive effects, not tainted by Nazi thought. It stimulated the investigation of the economic, social and cultural history of the Hanse, both in Eastern and Western Germany. ${ }^{65}$ Does this mean that contemporary political corsets were shed? Hardly. In the GDR, the focus of research lay predictably on class-struggle and the pan-European context of the Hanse was primarily Marxist-Leninist. The Hanse of towns (presented as an urban league in the late Middle Ages) was a welcome illustration of the fight against feudalism in medieval Europe. ${ }^{66}$ On the other hand, the end of the WWII triggered an urge to turn away from the nationalistic take on Hanseatic history. This is most apparent in the work of Heinrich Sproemberg, who presented the Hanse as a European research topic. This was due not only to the need to put Hanseatic sources in a larger framework, or to include non-German scholars in the discussions. The Hanse originated in Europe and it affected Europe. At the same time, the interpretation of this role of the Hanse was to be depoliticized. ${ }^{67}$ When Karl H. Schwebel presented an overview of Hanseatic historiography in the eighteenth and nineteenth centuries in 1964, he remarked that a new turn was about to take place. Forthwith, it was imperative to view the Hanse from a 'resentment-free and supranational vantage point'. ${ }^{68}$

Has putting the Hanse in a contemporary European context depoliticized it, or at least neutralized the use of its image? Not quite. At present, the Hanse is repeatedly sold to European customers in a twofold way. On the one hand, (regional) politicians and publicists point to it as the forerunner of the European Union, and a prime example of European economic integration and close cooperation of regions. Once again, wealthy citizens of towns, now in the twentieth century and in the whole of Europe, were invited to imagine themselves proudly as the heirs of the medieval Hansards. Several parallels have been evoked: the economic motive behind its existence, the extensive territory of the organization, its horizontal structures (limited hierarchy), the collective decision-taking,

the influence of Nazi propaganda, see for instance Henn (1994) 411. However, it is not entirely the case if one analyses Pagel's depiction of the Hanseatic-Hollandish relations.

65 Müller-Mertens (2003).

66 Henn (1994) 412; Selzer (2010) 10.

67 Sproemberg (1959). In this article, Sproemberg sought to underline the European context of the Hanse which was present in the work of Rörig.

68 Schwebel (1964) 20. 
the exchange of goods and ideas, as well as regional ties. Using the Hanse as a point of reference, cross-border cooperation initiatives have been taken like the 'Neue Hanse Interregio' (1991). ${ }^{69}$ Also, the 'City League the Hanse' (sic!) (also called the 'Hanseatic League of New Time' or the 'New Hansa') was forged in 1980 , with yearly 'Hanseatic days' as festive meetings of its members (who were, let us be honest, on a junket). By now the organization counts 176 member towns and cities in 16 European countries. ${ }^{70}$ The surge of interest in the Hanse, especially in the Baltic region, is directly connected to the changes which took place in Europe after 1989. The reunification of Germany, and the membership of the Baltic states in the European Union, have created a frothy enthusiasm for a shared 'Hanseatic past'. EU-membership and interregional cooperation is frequently presented as a continuation of old ties. Not all projects were successful in the long run: for instance in 1988, local politicians in SchleswigHolstein launched yet another initiative to create a 'New Hanse'. This met with a frosty response in Scandinavia, especially in Denmark: it was viewed as a stalking horse for a revival of German dominance in the region. ${ }^{71}$ This reaction was understood better by historians than by the politicians or the broad public. While scholars applaud the public's interest in history, they feel bound to caution against misleading interpretations. They remind us that the Hanse was an organization of traders speaking Low German, abiding by similar (though not the same) law and customs, not of the towns themselves. ${ }^{72}$ This has also consequences for the modern term 'Hanseatic town' and part of the 'City League the Hanse'. For instance Riga was a town in the Hanse because of the (German) merchants living there who traded overseas with the assistance of Hanseatic privileges. Riga's Hanseatic heritage is not limited to charming brick architecture and the historic flair of the Old Town. It also includes the (from today's point of view) foreign traders who made it Hanseatic. Comparisons between the area where the Hanseatic merchants were active and the entire European Union thus only works in a limited way: people and places are not related in the same manner.

69 Hill (2001) 67; see also Brand (2007).

70 http://www.hanse.org/en.

${ }^{71}$ Hill (2001) 67-69. For an overview of the Norwegian interpretation of this shared past, see Nedkvitne (1990).

72 Hammel-Kiesow (2007); Henn (1994) 413-4; Hill (2001) 67-9. 
This brings us to the second 'selling point' of the Hanse in Europe, namely as a product. Towns in the Baltic and North Sea area boast of their Hanseatic past in order to attract tourists and investment. Modern businessmen drape the mantel of the sober Hanseatic businessman around their own activities. For instance, the trading families in Hamburg-and the Chamber of Commerce (!) - point to the 'Ehrbarer Kaufmann' (honest merchant) as their collective forebear and inspiration. ${ }^{73}$ The list of products which are flogged under the Hanse label is endless, reaching from aviation (Lufthansa) to band aids (Hansaplast). ${ }^{74}$ It is obvious that the name is supposed to signal thoroughness, quality and tradition. The layer of historicism is intended to generate trust even in those potential customers who are not—or are only vaguely — familiar with the historical phenomenon itself. Most of these businesses are situated in Germany, but there are also examples from the Netherlands (Hanze Hogeschool in Groningen), Estonia (Hansa Grill in Tallinn), Poland (Hanza real estate in Gdańsk) or Norway (the brewery Hansabryggeri in Bergen). In most instances, the word 'Hanse' has little or nothing to do with the Hanse itself, but the places in which those businesses are located do have a Hanseatic past. ${ }^{75}$ Both in the case of parallels with the European Union, and the appropriation of the Hanse as a 'quality stamp' in advertising, the perception of the Hanse in a European context is a construct, leading a life of its own.

Thus, the Hanse game goes on. What will be the next round, in historical analysis and in historical reminiscence?

73 See the lengthy article on southern and northern trade traditions in Europe in one of the leading newspapers in the Netherlands (NRC Handelsblad 10 and 11.07.2010).

74 Selzer (2010) 1.

75 On the other hand, both Nuremberg and Munich, located well south of the last Hanseatic town, have a 'Hansa Street'. 
Map of the Hanse in 1554 according to the London Steelyard Statutes

Based on the map in Hammel-Kiesow, R., Puhle, M. and S. Wittenburg (phot.) (2009) Die Hanse (Darmstadt: 2009). We kindly thank Rolf HammelKiesow and Matthias Puhle for their permission to use the map.

As stated earlier, all maps of the Hanse are snapshots: it is not possible to draw one complete map of Hanse members.

\section{Glossary:}

Braunsberg/ Braniewo

Breslau/ Wrocław

Danzig/Gdańsk

Dorpat/ Tartu

Elbing/ Elbląg

Gollnow/ Goleń

Kolberg/ Kołobrzeg

Köln (Cologne)

Königsberg/ Kaliningrad

Krakau/ Kraków

Kulm/ Chełmno

Nimwegen/ Nijmegen

Raseborg/ Raasepori

Reval/ Tallinn

Rügenwalde/ Darłowo

Staveren/ Stavoren

Stettin/ Szczecin

Stolp/ Słupsk

Thorn/ Toruń

Åbo/Turku 


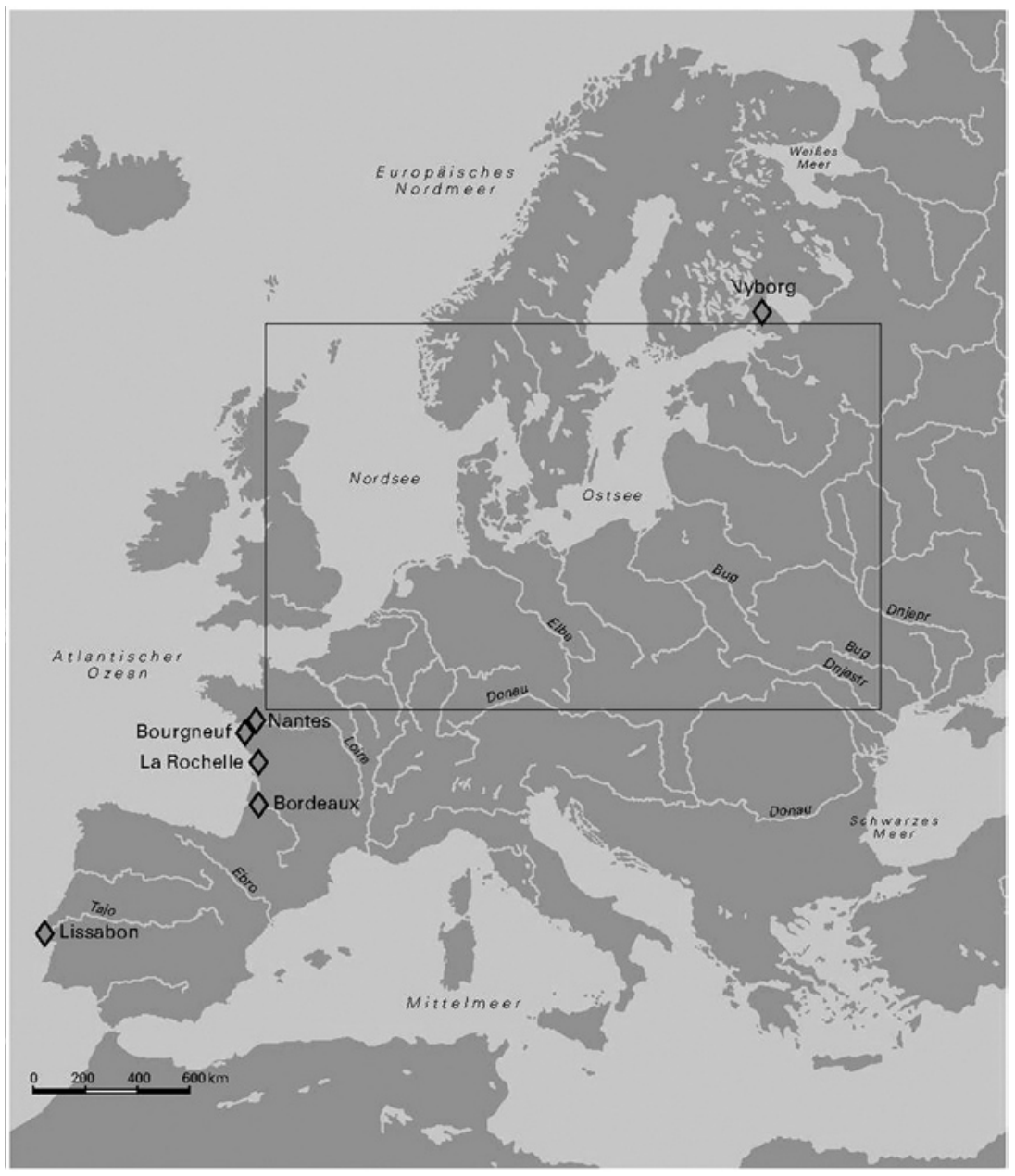




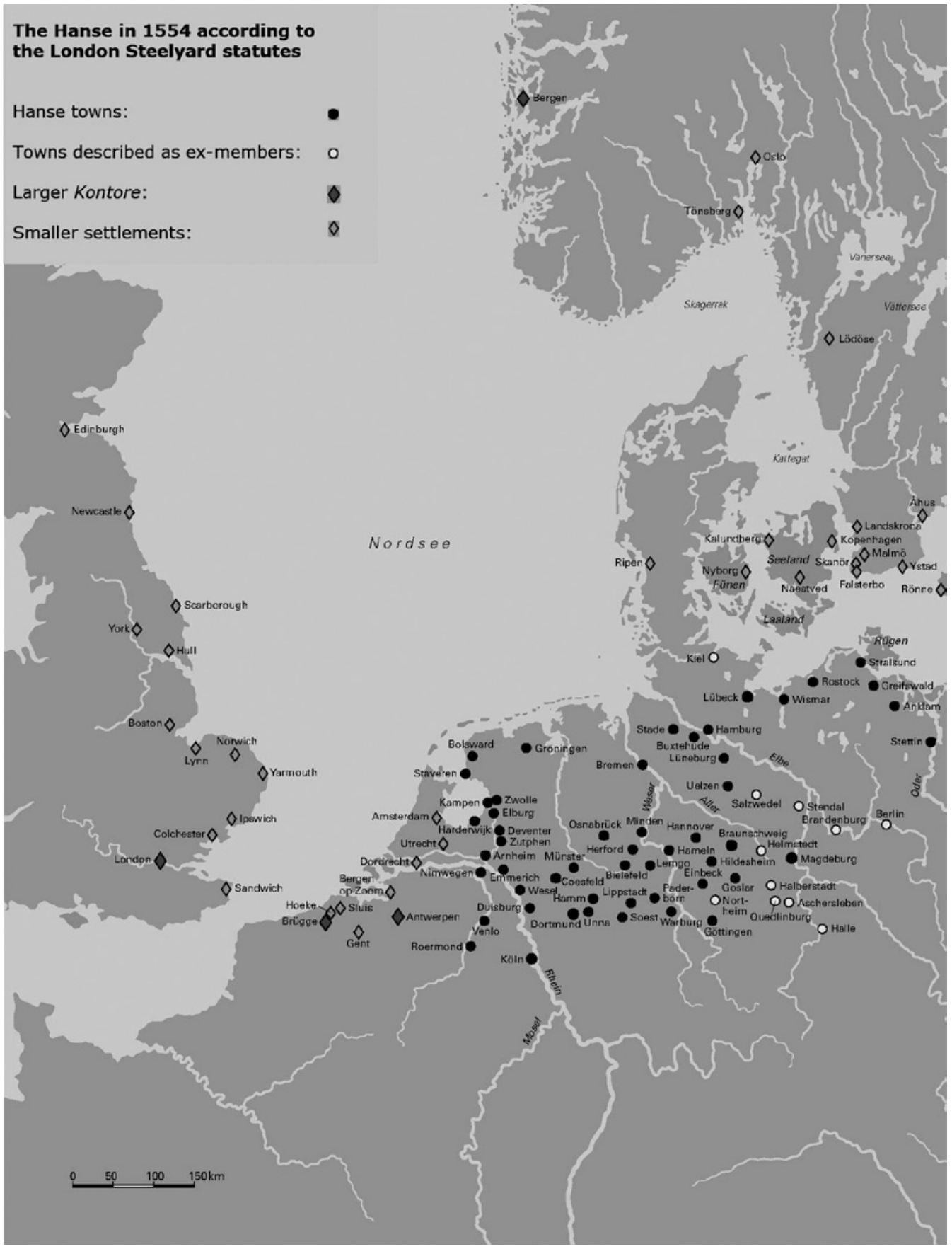




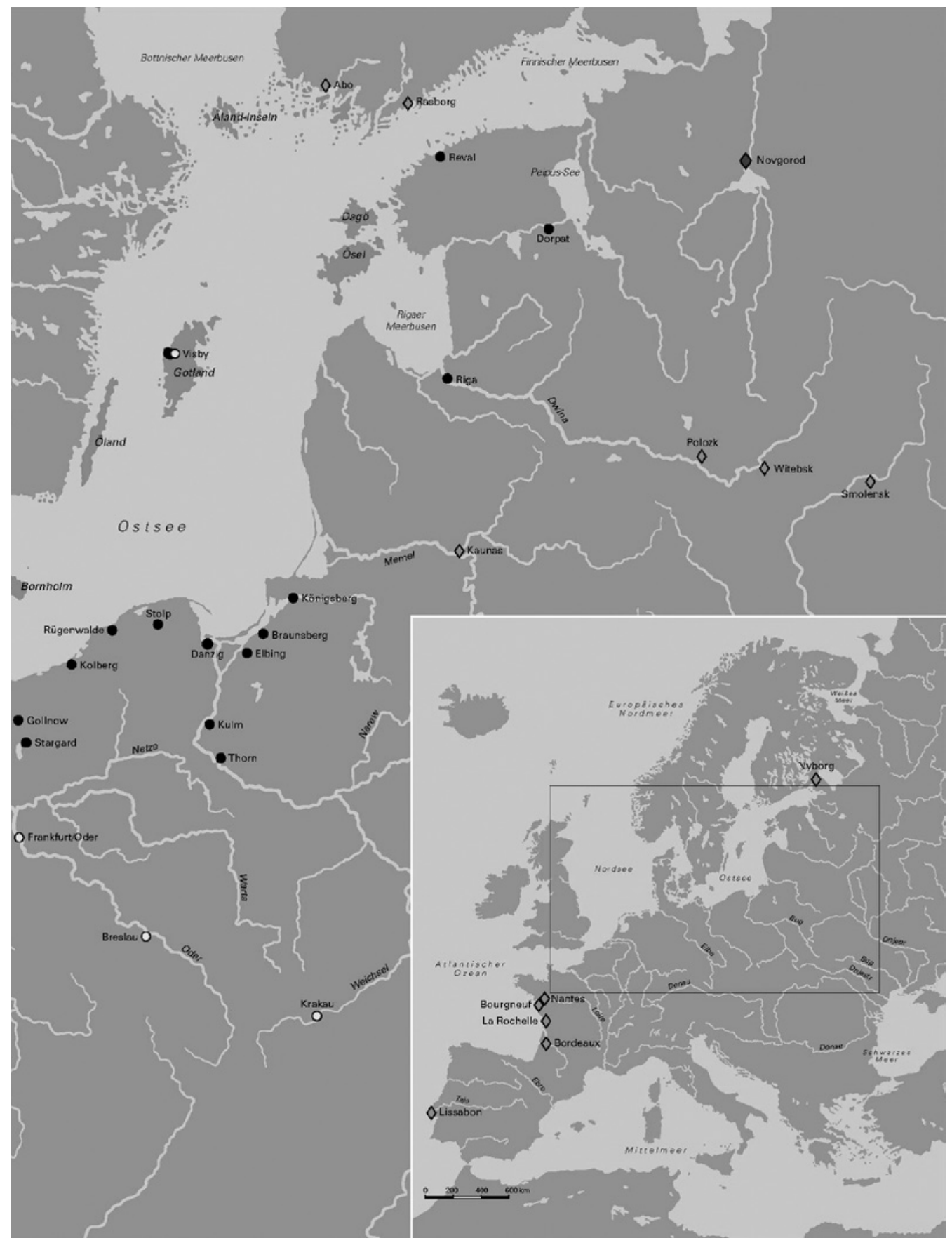




\section{Guide to Hanse Research}

1) Central source editions

HR: Hanserecesse/Hanserezesse (Leipzig: 1870-1970), 4 series and a total of 26 volumes.

(Partly digitized, see www.hansischergeschichtsverein.de, 'Publikationen').

HUB: Hansisches Urkundenbuch, (Halle: 1876-1939), 11 volumes. (Partly digitized, idem).

2) Presentation of Sample sources

Sprandel, R. ed., Quellen zur Hanse-Geschichte (Darmstadt: 1982).

3) Main Journal

Hansische Geschichtsblätter (1871-), with an extensive review section: 'Hansische Umschau'.

4) Selected general overviews

Dollinger, Ph. (1997) Die Hanse, 5th ed. (Stuttgart: 1997).

Friedland, K. (1991) Die Hanse (Stuttgart: 1991).

Hammel-Kiesow, R. (2008) Die Hanse, 4th ed. (München: 2008).

Hammel-Kiesow, R., Puhle, M. and S. Wittenburg (phot.) (2009) Die Hanse (Darmstadt: 2009).

Selzer, S. (2010) Die mittelalterliche Hanse (Darmstadt: 2010).

Schildhauer, J. (1984) Die Hanse. Geschichte und Kultur (Leipzig: 1984).

5) Comprehensive EXHiBition COMPANion

Bracker, J. et al. eds., Die Hanse. Lebenswirklichkeit und Mythos, 3rd ed. (Lübeck: 1999).

6) Selected edited Volumes

Brand, H. and E. Knoll eds. (2010) Koggen, Kooplieden en Kantoren. De Hanze, een praktisch netwerk, 2nd ed. (Hilversum: 2010).

Cordes, A. ed. (2008) Hansisches und hansestädtisches Recht, Hansische Studien 19 (Trier: 2008).

Graßmann, A. ed. (1998) Niedergang oder Übergang? Zur Spätzeit der Hanse im 16. und 17. Jahrhundert, Quellen und Darstellungen zur hansischen Geschichte NF 44 (Köln: 1998).

Hammel-Kiesow, R. ed. (2002) Vergleichende Ansätze in der hansischen Geschichtsforschung, Hansische Studien 13 (Trier: 2002).

Hammel-Kiesow, R. and R. Holbach eds. (2010) Geschichtsbewusstsein in der Gesellschaft. Konstrukte der Hanse in den Medien und in der Öffentlichkeit, Hansische Studien 19 (Trier: 2010).

Müller-Mertens, E. and H. Böcker eds. (2003) Konzeptionelle Ansätze der HanseHistoriographie, Hansische Studien 14 (Trier: 2003).

North, M. and S. Jenks (1993) Der hansische Sonderweg? Beiträge zur Sozial- und Wirtschaftsgeschichte der Hanse, Quellen und Darstellungen zur hansischen Geschichte NF 39 (Köln: 1993).

Sarnowsky, J. ed. (2006) Verwaltung und Schriftlichkeit in den Hansestädten, Hansische Studien 16 (Trier: 2006).

Wernicke, H. and N. Jörn eds. (1998) Beiträge zur hansischen Kultur-, Verfassungsund Schiffahrtsgeschichte, Hansische Studien 10 = Abhandlungen zur Handels- und Sozialgeschichte 31 (Weimar: 1998).

7) ONLINE PUBLICATION (AND IN THE FUTURE BOOK PUBLICATION)

www.hanselexikon.de

8) INTERNET GUIDE TO SOME OF THE ARCHIVES CENTRAL FOR HANSE RESEARCH

http://www.balticconnections.net/, see also Bes, L., Frankot E. and H. Brand eds. Baltic Connections: Archival Guide to the Maritime Relations of the Countries around the Baltic Sea (including the Netherlands) 1450-1800, The Northern World 36 (Leiden/Boston: 2007). 


\section{Bibliography}

Abraham-Thisse, S. (2002) 'Der Tuchhandel der Hanse am Ende des Mittelalters (14.-15. Jahrhundert)', in Hammel-Kiesow, R. ed., Vergleichende Ansätze in der hansischen Geschichtsforschung (Trier: 2002) 183-207.

Angermann, N. and K. Friedland eds. (2002) Novgorod. Markt und Kontor der Hanse (Köln: 2002).

Asche, M. (1999) 'Der Ostseeraum als Universitäts- und Bildungslandschaft im Spätmittelalter und in der Frühen Neuzeit-Baustein für eine hansische Kulturgeschichte', Blätter für deutsche Landesgeschichte 135 (1999) 1-20.

Asmussen, G. (1999) Die Lübecker Flandernfahrer in der zweiten Hälfte des 14. Jahrhunderts (1358-1408) (Frankfurt am Main: 1999).

Behrmann, T. (1999) “'Hansekaufmann', 'Hansestadt', 'Deutsche Hanse'? Über hansische Terminologie und hansisches Selbstverständnis im späten Mittelalter' in Scharff, T. and T. Behrmann eds., Bene vivere in communitate. Beiträge zum italienischen und deutschen Mittelalter (Münster: 1999) 155-75.

— (2004) Herrscher und Hansestädte. Studien zum diplomatischen Verkehr im Spätmittelalter (Hamburg: 2004).

Blanckenburg, Ch. von (2001) Die Hanse und ihr Bier: Brauwesen und Bierhandel im hansischen Verkehrsgebiet (Köln: 2001).

Blockmans, W. (1993) 'Der holländische Durchbruch in der Ostsee', in Jenks, S. and M. North eds., Der hansische Sonderweg? Beiträge zur Sozial- und Wirtschaftsgeschichte der Hanse (Köln: 1993) 49-58.

Boer, D. (2000) 'Brügge-London-Ostseeraum', in Paravicini, W., H. Wernicke and N. Jörn eds., Hansekaufleute in Brügge. Teil 4: Beiträge der internationalen Tagung in Brügge April 1996 (Frankfurt am Main: 2000) 55-69.

Bogucka, M. (2003) Baltic commerce and urban society, 1500-1700: Gdańsk/Danzig and its Polish context (Aldershot: 2003).

Böcker, H. (1999) 'Gruppenbindungen und -brüche. Symbolwerte in der privaten 'Gegenrechnung' des Fernhandels-Kaufmanns Hildebrand Veckinchusen um die Wende vom 14. zum 15. Jahrhundert', in Jörn, N., D. Kattinger and H. Wernicke eds., "kopet uns werk by tiden". Beiträge zur hansischen und preußischen Geschichte. Walter Stark zum 75 . Geburtstag (Schwerin: 1999) 143-52.

Brand, H. ed. (2007) The German Hanse in Past \& Present Europe. A medieval League as a model for modern interregional cooperation? (Groningen: 2007).

Brandt, A. von (1962) Die Hanse und die nordischen Mächte im Mittelalter (Köln: 1962).

_ (1963) 'Die Hanse als mittelalterliche Wirtschaftsorganisation-Entstehung, Daseinsformen, Aufgaben', in Brandt A. von et al. eds., Die deutsche Hanse als Mittler zwischen Ost und West (Köln: 1963) 9-37.

Bund, K. (1973) Hanse in Europa: Brücke zwischen den Märkten 12.-17. Jahrhundert: Ausstellung des Kölnischen Stadtmuseums, 9. Juni-9. Sept. 1973, Kunsthalle Köln (Köln: 1973).

Burkhardt, M. (2009) Die Geschichte des Bergenhandels im Spätmittelalter. HandelKaufleute-Netzwerke, Quellen und Darstellungen zur hansischen Geschichte NF 6o (Köln: 2009).

Czaja, R. (2000) 'Regionale und hansische Identität des preußischen Bürgertums', in Tandecki, J. ed., Die Rolle der Stadtgemeinden und bürgerlichen Genossenschaften im Hanseraum in der Entwicklung und Vermittlung des gesellschaftlichen und kulturellen Gedankengutes im Spätmittelalter (Toruń: 2000) 91-101.

Dalen, A, (1994) 'The Influence of Low German on the Norwegian Language', in Henn, V. and A. Nedkvitne eds., Norwegen und die Hanse (Kieler Werkstücke A 11) (Frankfurt: 1994) 31-9. 
Distler, E.-M. (2006) Städtebünde im deutschen Spätmittelalter: eine rechtshistorische Untersuchung zu Begriff, Verfassung und Funktion (Frankfurt am Main: 2006).

Ellmers, D. (2010) 'Koggen kontrovers', Hansische Geschichtsblätter 128 (2010) 113-40.

Fahlbusch, B. (1994) 'Regionale Identität. Eine Beschreibungskategorie für den hansischen Teilraum Westfalen um 1470?', Hansische Geschichtsblätter 112 (1994) 139-59.

Fouquet, G. (2006) 'Kaufleute auf Reisen'. Sprachliche Verständigung im Europa des 14. und 15. Jahrhunderts', in Schwinges, R.C., Ch. Hesse and P. Moraw eds., Europa im späten Mittelalter (München: 2006) 465-87.

Friedland, K. (1991) Die Hanse (Stuttgart: 1991).

— (1999) 'Der Gemeine Kaufmann', in Jörn, N., D. Kattinger and H. Wernicke eds., Genossenschaftliche Strukturen in der Hanse, Quellen und Darstellungen zur hansischen Geschichte NF 48 (Köln: 1999) 287-94.

Grafe R. and O. Gelderblom (2010) 'The Rise and Fall of the Merchant Guilds: Re-thinking the Comparative Study of Commercial Institutions in Premodern Europe', Journal of Interdisciplinary History 40/4 (2010) 477-511.

Graßmann, A. ed. (1998) Niedergang oder Übergang? Zur Spätzeit der Hanse im 16. und 17. Jahrhundert, Quellen und Darstellungen zur hansischen Geschichte NF 44 (Köln: 1998).

— ed. (2005) Das Hansische Kontor zu Bergen und die Lübecker Bergenfahrer. International Workshop Lübeck 2003 (Lübeck: 2005).

— ed. (2009) Der Kaufmann und der liebe Gott: zu Kommerz und Kirche in Mittelalter und Früher Neuzeit, Hansische Studien 18 (Trier: 2009).

- (2009b) 'Kirchliches Leben in den hansischen Niederlassungen des Auslandes', in Graßmann, A. ed., Der Kaufmann und der liebe Gott: zu Kommerz und Kirche in Mittelalter und Früher Neuzeit, Hansische Studien 18 (Trier: 2009).

Hammel-Kiesow, R. (1999) 'Wer kaufte die Waren des hansischen Handels? Eine Annäherung an die Endverbraucher', in Jörn, N., D. Kattinger and H. Wernicke eds., "kopet uns werk by tiden". Beiträge zur hansischen und preußischen Geschichte. Walter Stark zum 75. Geburtstag (Schwerin: 1999) 73-80.

- (2002) Die Hanse, 2nd ed. (München: 2002).

_ (2007) 'Europäische Union, Globalisierung und Hanse. Überlegungen zur aktuellen Vereinnahmung eines historischen Phänomens', Hansische Geschichtsblätter 125 (2007) $1-44$.

- (2008) 'Schriftlichkeit und Handelsgesellschaften niederdeutsch-hansischer und oberdeutscher Kaufleute im späten 13. und im 14. Jahrhundert', in Heckmann, M.-L. and J. Röhrkasten eds., Von Nowgorod bis London. Studien zu Handel, Wirtschaft und Gesellschaft im mittelalterlichen Europa, Nova Mediaevalia 4 (Göttingen: 2008) 213-41.

Hammel-Kiesow, R., Puhle, M. and S. Wittenburg (phot.) (2009) Die Hanse (Darmstadt: 2009).

Heerma van Voss, L. and E. van Nederveen Meerkerk (2007) 'The Hanse and after. State formation, merchant elites and the efficiency of institutions in the Hanse and Holland c. 1400-1680', in Brand, H. ed., The German Hanse in Past \& Present Europe. A medieval League as a model for modern interregional cooperation? (Groningen: 2007) 221-46.

Henn, V. (1984) 'Die Hanse: Interessengemeinschaft oder Städtebund?', Hansische Geschichtsblätter 102 (1984) 119-26.

_ (1994) 'Wege und Irrwege der Hanseforschung und Hanserezeption in Deutschland im 19. und 20. Jahrhundert', in Nikolay-Panter, M., W. Janssen and W. Herborn eds., Geschichtliche Landeskunde der Rheinlande. Regionale Befunde und raumübergreifende Perspektiven (Köln: 1994) 388-414.

- (1999) 'Was war die Hanse?', in Bracker, J. et al. eds., Die Hanse. Lebenswirklichkeit und Mythos, 3rd ed. (Lübeck: 1999) 14-23.

ed. (2001) Die hansischen Tagfahrten zwischen Anspruch und Wirklichkeit, Hansische Studien 11 (Trier: 2001).

- (2002) 'Kommunikative Beziehungen und binnenhansisches Raumgefüge', in Hammel-Kiesow, R. ed., Vergleichende Ansätze in der hansischen Geschichtsforschung, Hansische Studien 13 (Trier: 2002) 33-42. 
- (2008) 'Die Hansekontore und ihre Ordnungen', in Cordes, A. ed., Hansisches und hansestädtisches Recht, Hansische Studien 17 (Trier: 2008) 15-39.

- (2010) 'Het ontstaan van de Hanze', in Brand, H. and E. Knoll eds., Koggen, Kooplieden en Kantoren. De Hanze, een praktisch netwerk, 2nd ed. (Hilversum: 2010) 10-25.

Henn, V. and J. Sarnowsky eds. (2010) Das Bild der Hanse in der städtischen Geschichtsschreibung des Mittelalters und der frühen Neuzeit, Hansische Studien 20 (Trier: 2010).

Hill, T. (2001) 'Vom öffentlichen Gebrauch der Hansegeschichte und Hanseforschung im 19. und 20. Jahrhundert', in Graßmann, A. ed., Ausklang und Nachklang der Hanse im 19. und 20. Jahrhundert, Hansische Studien 12 (Trier: 2001) 67-88.

Holbach, R. (2007) 'Cloth production, Hanseatic cloth trade and trade policy (14th to 16th century)', in Brand, H. ed., The German Hanse in Past \& Present Europe. A medieval League as a model for modern interregional cooperation? (Groningen: 2007) 71-93.

Hoppenbrouwers, P. (2010) 'The Dynamics of National Identity in the Later Middle Ages', in Stein, R. and J. Pollmann eds., Networks, Regions and Nations. Shaping Identities in the Low Countries, 1300-1650 (Leiden: 2010) 19-41.

Irsigler, F. (1998) 'Erscheinungsbild und Erfahrungswelt des hansischen Kaufmanns', in Jörn, N. and H. Wernicke eds., Beiträge zur hansischen Kultur-, Verfassungs- und Schiffahrtsgeschichte (Weimar: 1998) 11-22.

Jaacks, G. (1999) 'Kunst in der Hansestadt-Repräsentation und Vermittlung', in Bracker, J. et al. eds., Die Hanse. Lebenswirklichkeit und Mythos, 3rd ed. (Lübeck: 1999) 508-24.

Jahr, E.H. ed. (1995) Nordisk og nedertysk. Språkkontakt og språkutvikling i seinmellomalderen (Oslo: 1995).

Jakobsson, S. (1999) 'Defining a Nation: Popular and Public Identity in the Middle Ages', Scandinavian Journal of History 24 (1999) 91-101.

Jenks, S. (1992) 'Werkzeug des spätmittelalterlichen Kaufmanns: Hansen und Engländer im Wandel von memoria zur Akte (mit einer Edition von The Noumbre of Weyghtys)', in Schneider, J. and G. Rechter eds., Festschrift Alfred Wendehorst zum 65. Geburtstag gewidmet von Kollegen, Freunden, Schülern, 2 vols. = Jahrbuch für fränkische Landesforschung 52-53 (1992), vol. 1, 283-319.

_- (1996) 'Zum hansischen Gästerecht', Hansische Geschichtsblätter 114 (1996) 3-59.

- (2005) 'Transaktionskostentheorie und die mittelalterliche Hanse', Hansische Geschichtsblätter 123 (2005) 31-42.

- (2010) 'Concurrentie' in Brand, H. and E. Knoll eds., Koggen, Kooplieden en Kantoren. De Hanze, een praktisch netwerk, 2nd ed. (Hilversum: 2010) 79-89.

Jörn, N. et al. eds. (1998a) Der Stralsunder Frieden von 1370. Prosopographische Studien, Quellen und Darstellungen zur hansischen Geschichte NF 46 (Köln: 1998).

Jörn, N. (1998b) 'The crocodile creature merchant: the Dutch Hansa. Die Widerspiegelung der englisch-hansischen Auseinandersetzungen in den Denkschriften englischer Kaufleute und Politiker in der 2. Hälfte des 16. Jahrhunderts' in Graßmann, A. ed., Niedergang oder Übergang? Zur Spätzeit der Hanse im 16. und 17. Jh., Quellen und Dratsellungen zur hansischen Geschichte NF 44 (Köln: 1998) 63-91.

- (2000) 'Die Herausbildung der Kontorordnungen in Novgorod, Bergen, London und Brügge im Vergleich-12.-17. Jahrhundert' in Ruhe, D. and K.-H. Spiess eds., Prozesse der Normbildung und Normveränderung im mittelalterlichen Europa (Stuttgart: 2000) 217-35.

Mohrmann, R.-E. ed. (1996) Nahrung und Tischkultur im Hanseraum (Münster: 1996).

Moraw, P. (2002) 'Hansestädte, König und Reich im späteren Mittelalter', in HammelKiesow, R. ed., Vergleichende Ansätze in der hansischen Geschichtsforschung, Hansische Studien 13 (Trier: 2002) 53-76.

Munro, J. (1994) Textiles, towns and trade: essays in the economic history of late-medieval England and the Low Countries (Aldershot: 1994).

Müller-Mertens, E. (2003) 'Die Hanse in europäischer Sicht. Zu den konzeptionellen Neuansätzen der Nachkriegszeit und zu Rörigs Konzept', in Müller-Mertens, E. and H. Böcker eds., Konzeptionelle Ansätze der Hanse-Historiographie, Hansische Studien 14 (Trier: 2003) 19-43. 
Müller-Mertens, E. and H. Böcker eds. (2003) Konzeptionelle Ansätze der HanseHistoriographie, Hansische Studien 14 (Trier: 2003).

Nedkvitne, A. (1990) 'The Hansa in Norway as seen by Norwegian historians today', in Die Hanse und Nordeuropa: Handel-Politik-Kultur. Synthesekonzepte in der Geschichtsschreibung: Bericht über das 4. Deutsch-norwegische Historikertreffen in Berlin, Mai 1989 / Deutsch-Norwegisches Stipendienprogramm für Geschichtswissenschaften (Oslo: 1990) 52-64.

Niebaum, H. (2010) 'Taal en communicatie in het Hanzegebied', in Brand, H. and E. Knoll eds., Koggen, Kooplieden en Kantoren. De Hanze, een praktisch netwerk, 2nd ed. (Hilversum: 2010) 160-9.

Nordhagen, P.J. (1994) 'Das Hanse-Problem in der norwegischen Kunstgeschichte. Der Zusammenbruch der Kunstproduktion in Norwegen im Spätmittelalter', in Henn, V. and A. Nedkvitne eds., Norwegen und die Hanse. Wirtschaftliche und kulturelle Aspekte im europäischen Vergleich (Frankfurt am Main: 1994) 41-73.

Oexle, O.G. (1989) 'Gilde', in Lexikon des Mittelalters vol IV (München: 1989) 1452-1453.

Pagel, K. (1943) Die Hanse (Oldenburg: 1943).

Paulsen, R. (2010) 'Die Koggendiskussion in der Forschung. Methodische Probleme und ideologische Verzerrungen', Hansische Geschichtsblätter 128 (2010) 19-112.

Pelus-Kaplan, M.-L. (2007) 'Merchants and immigrants in Hanseatic cities, c. 1500-1700', in Calabi, D. and S.T. Christensen eds., Cultural Exchange in Early Modern Europe. II Cities and Cultural Exchange in Europe (Cambridge: 2007) 132-53.

Peters, R. (1987) 'Das mittelniederdeutsche als Sprache der Hanse', in Sture Ureland, P. ed., Sprachkontakt in der Hanse. Aspekte des Sprachausgleichs im Ostsee- und Nordseeraum. Akten des 7. internationalen Symposiums über Sprachkontakt in Europa, Lübeck 1986 (Tübingen: 1987) 65-88.

Pilecka, E. (1994) 'Charakter hanzeatyckiej sztuki miast pruskich późnego średniowiecza na przykładzie sakralnej architektury Gdańska', in Woźniak, M. ed., Sztuka Prus XIIIXVIII w. (Toruń: 1994) 39-69. ('The character of the Hanseatic art of the late medieval Prussian towns: the example of sacral architecture in Gdańsk').

Pichierri, A. (2000) Die Hanse-Staat der Städte. Ein ökonomisches und politisches Modell der Städtevernetzung (Opladen: 200o).

Pitz, E. (1984) 'Steigende und fallende Tendenzen in Politik und Wirtschaftsleben der Hanse im 16. Jahrhundert', Hansische Geschichtsblätter 102 (1984) 39-77.

- (2001) Bürgereinung und Städteeinung. Studien zur Verfassungsgeschichte der Hansestädte und der deutschen Hanse, Quellen und Darstellungen zur hansischen Geschichte NF 52 (Köln: 2001).

Poeck, D. (1991) 'Totengedenken in Hansestädten. Formen der "memoria"', in Neiske, F., Poeck, D. and M. Sandmann eds., Vinculum Societatis. Joachim Wollasch zum 60. Geburtstag (Sigmaringen: 1991) 175-232.

Postel, R. (1999) 'Der Niedergang der Hanse' in Bracker, J. et al. eds., Die Hanse. Lebenswirklichkeit und Mythos, 3rd ed. (Lübeck: 1999) 165-93.

- (2009) 'eyne gans nye ferlicke secte-die Hansestädte und die Reformation' in Graßmann, A. ed., Der Kaufmann und der liebe Gott: zu Kommerz und Kirche in Mittelalter und Früher Neuzeit (Trier: 2009) 131-45.

Puhle, M. (1999) 'Organisationsmerkmale der Hanse' in Bracker, J. et al. eds., Die Hanse. Lebenswirklichkeit und Mythos, 3rd ed. (Lübeck: 1999) 196-201.

Rahn, K. (1999) 'Wirkungsfelder religiöser Bruderschaften in spätmittelalterlichen Städten der sächsischen und wendischen Hanse', in Jörn, N. Kattinger, D. and H. Wernicke eds., Genossenschaftliche Strukturen in der Hanse, Quellen und Darstellungen zur hansischen Geschichte NF 48 (Köln: 1999) 165-80.

Rambø, G.-R. (2008) Historiske og sosiale betingelser for språkkontakt mellom nedertysk og de skandinaviske språkene $i$ seinmiddelalderen-et bidrag til historisk språksosiologi (unpublished $\mathrm{PhD}$ dissertation, University of Agder).

Rörig, F. (1940) Vom Wesen und Werden der Hanse (Leipzig: 1940). 
Rößner, R. (2010) Hansische Memoria in Flandern: Alltagsleben und Totengedenken der Osterlinge in Brügge und Antwerpen (13. bis 16. Jahrhundert) (Frankfurt am Main 2001).

Sartorius, G.F. (1802-1808) Geschichte des Hanseatischen Bundes und Handels, 3 vols. (Göttingen: 1802-1808).

Schäfer, D. (1913) Aufsätze, Vorträge und Reden (Jena: 1913).

Schildhauer, J. (1984) Die Hanse. Geschichte und Kultur (Leipzig: 1984).

Schmidt-Wiegand, R. (1999) 'Genossenschaftliche Organisation im Spiegel historischer Bezeichnungen. Hanse, Gilde, Morgensprache', in Jörn, N., D. Kattinger and H. Wernicke eds., Genossenschaftliche Strukturen in der Hanse, Quellen und Darstellungen zur hansischen Geschichte NF 48 (Köln: 1999) 1-12.

Schubert, B. (2002) 'Hansische Kaufleute im Novgoroder Handelskontor', in Angermann, N. and K. Friedland eds., Novgorod. Markt und Kontor der Hanse, Quellen und Darstellungen zur hansischen Geschichte NF 53 (Köln: 2002) 79-96.

Schubert, E. (2002) 'Novgorod, Brügge, Bergen und London: Die Kontore der Hanse', Concilium medii aevi 5 (2002) 1-50.

Schwebel, K.H. (1964) 'Zur Historiographie der Hanse im Zeitalter der Aufklärung und der Romantik', Hansische Geschichtsblätter 82 (1964) 1-20.

___ (1970) Der Stralsunder Friede (1370) im Spiegel der historischen Literatur (Bremen: 1970).

Seifert, D. (1997) Kompagnons und Konkurrenten. Holland und die Hanse im späten Mittelalter (Köln: 1997).

Selzer, S., and U.C. Ewert (2001) 'Verhandeln und verkaufen, vernetzen und vertrauen. Über die Netzwerkstruktur des hansischen Handels', Hansische Geschichtsblätter 119 (2001) 135-62.

Selzer, S. (2010) Die mittelalterliche Hanse (Darmstadt: 2010).

Smith, A.D. (2004) The antiquity of nations (Cambridge 2004).

Sproemberg, H. (1959) 'Die Hanse in europäischer Sicht', in Alberts, J.A. ed., Dancwerc: opstellen aangeboden aan Prof. Dr. D.Th. Enklaar ter gelegenheid van zijn vijfenzestigste verjaardag (Groningen: 1959) 127-51.

Stabel, P. (2000) 'Marketing Cloth in the Low Countries: Manufacturers, Brokers and Merchants (14th-16th centuries)' in Stabel, P., B. Blondé and A. Greve eds., International Trade in the Low Countries (14th-16th Centuries). Merchants, Organisation, Infrastructure (Leuven: 2000) 15-36.

Stoob, H. (1995) Die Hanse (Graz: 1995).

Unger, R.W. (2004) Beer in the Middle Ages and the Renaissance (Philadelphia: 2004).

Vogel, W. (1915) Kurze Geschichte der Deutchen Hanse (München: 1915).

von Bonsdorff, J. (1993) Kunstproduktion und Kunstverbreitung im Ostseeraum des Spätmittelalters (Helsinki: 1993).

Waitz, G. (1855) Lübeck unter Jürgen Wullenwever und die europäische Politik (Göttingen: 1855).

Wernicke, H. (1983) Die Städtehanse 1280-1418. Genesis-Strukturen-Funktionen (Weimar: 1983).

Wriedt, K. (2005) Schule und Universität. Bildungsverhältnisse in norddeutschen Städten des Spätmittelalters. Gesammelte Aufsätze (Leiden: 2005).

Wubs-Mrozewicz, J. (2006) 'Hinrick van Hasselt. Problemlösung in Bergen in den 4oer Jahren des 16. Jahrhunderts', Hansische Geschichtsblätter 124 (2006) 1-20.

- (2008) Traders, Ties and Tensions. The Interaction of Lübeckers, Overijsslers and Hollanders in Late Medieval Bergen (Hilversum: 2008).

- (2011) 'Rules of Inclusion, Rules of Exclusion: The Hanseatic Kontor in Bergen in the Late Middle Ages and its Normative Boundaries', German History 29/1 (2011) 1-22.

- (forthcoming) 'Framing alterities and identities in medieval and post-medieval Europe. The case of Hollanders as the 'Other' in Hanseatic sources and German historiography' (on the basis of a paper presented at the European Social Science History Conference, Ghent 2010).

Zaske, N. and R. (1986) Kunst in Hansestädten (Köln: 1986). 